\title{
SEKS PRANIKAH PADA REMAJA DI POLI PKPR UPTD PUSKESMAS SANANWETAN KOTA BLITAR
}

\author{
Sunarti ${ }^{1}$, Sri Winarni ${ }^{2}$, Dina ${ }^{3}$ \\ 1,2,3, Poltekkes Kemenkes Malang \\ *Email : s.kepsunarti@yahoo.co.id
}

\begin{abstract}
Abstrak
Aktifitas seks yang terjadi pada remaja yang belum melakukan pernikahan saat ini merupakan fenomena yang banyak dilakukan oleh remaja. Maraknya tontonan dan bacaan porno, kurangnya perhatian dari orang tua dan maraknya gaya berpacaran tidak sehat mengakibatkan terjadinya seks pranikah. Tujuan penelitian ini adalah mengidentifikasi tentang seks pranikah di Poli PKPR UPTD Puskesmas Sananwetan Kota Blitar. Desain penelitian yang digunakan adalah metode studi kasus (case study). Penelitian ini menggunakan 2 responden remaja perempuan dengan metode wawancara. Pengumpulan data dilakukan dengan tanggal yang berbeda pada tiap responden, responden pertama pada tanggal 22 April 2018 dan responden kedua pada tanggal 17 April 2018. Hasil penelitian menunjukan bahwa remaja yang berpacaran tidak sehat cenderung melakukan hubungan seksual sebelum menikah (seks pranikah), dan aktifitas seksual yang dilakukan tidak menggunakan 4 tahapan yaitu bersentuhan (touching), berciuman (kissing), bercumbu (petting), dan berhubungan kelamin (seksual intercourse), melainkan menggunakan tahapan tanpa melakukan bercumbu (petting). Hendaknya Poli PKPR menghimbau lebih intensif dalam memberikan sosialisasi dan bekerjasama dengan orangtua dan dinaspendidikan untuk lebih memperhatikan remaja dalam pergaulannya terutama dalam gaya berpacaran yang tidak sehat.
\end{abstract}

Kata Kunci : Seks, pranikah, remaja

\section{Abstract}

Premarital Sex In Adolescents Un Poli Pkpr Uptd Puskesmas Sananwetan Blitar City. Sex activities that occur in teenagers who have not been married at this time is a phenomenon that many do by adolescents. The rise of spectacle and porn reading, the lack of attention from parents and the rise of unhealthy courtship style resulted in premital sex. The purpose of this study was to identify about premarital sex in Poly PKPR UPTD Puskesmas Sananwetan Blitar. The research designed used is case study method. This study used 2 female adolescent respondents with interview method. Data collection was conducted with different dates on each respondent, first respondent on April 22, 2018 and second respondent on April 17, 2018. The results showed that teenagers who are unhealthy dating tend to have sexual intercourse before marriage (premarital sex), and sexual activity which do not use 4 stages of touching, kissing, petting, and sex (sexual intercourse), but using stages without making petting. Poly PKPR should urge more intensively in providing socialization and cooperation with parents and education offices to pay more attention to adolescents in the association, especially in unhealthy dating style.

Keywords : Sex, premarital, adolescen 


\section{Pendahuluan}

Masa remaja merupakan masa peralihan antara masa anak-anak yang dimulai saat terjadinya kematangan seksual yaitu antara usia 11 atau 12 tahun sampai dengan 20 tahun, yaitu masa menjelang dewasa muda, masa remaja dimulai dengan munculnya pubertas, sebuah periode dimana perubahan fisik terjadi secara pesat pada setiap individu. Masa ini ditandai dengan munculnya karakteristik seksual sekunder. Selama masa ini, tidak hanya perubahan fisik yang terjadi tetapi juga perubahan perilaku serta peran pada individu pun berubah, salah satu perubahan tersebut adalah remaja mulai tertarik dengan lawan jenisnya (Soetjiningsih, 2007). Salah satu permasalahan di masa remaja adalah mengenai perilaku seksual. Perilaku seksual merupakan segala tingkah laku yang didorong oleh hasrat seksual bagi lawan jenis maupun sesama jenis. Bentuk tingkah laku seksual bisa bermacam-macam, mulai dari perasaan tertarik sampai tingkah laku berkencan, bercumbu, bersenggama (Sarwono, 2015).

Di Jawa Timur perilaku seksual pranikah pada remaja usia 15 hingga 24 tahun terus meningkat setiap tahun, menurut
(SDKI,2012) terjadi peningkatan hubungan seks pranikah remaja usia 15-24 tahun. Survey yang menggunakan data sekunder SDKI 2012 tentang kesehatan reproduksi remaja ini dilakukan terhadap remaja perempuan dan laki-laki yang belum menikah. Hasilnya 8,3 \% remaja laki-laki dan $1 \%$ remaja perempuan melakukan hubungan seks pranikah. Hubungan seksual terbanyak dilakukan pada remaja usia 15-19 tahun sebesar 2,7\% (Agustin, 2014). Data Dinas Kesehatan Kota Blitar menjelaskan bahwa masalah seks pranikah mengalami peningkatan dalam 2 tahun terakhir ini yakni pada tahun 2016 jumlah anak yang hamil adalah 97 anak, dengan jumlah anak yang melakukan seks sebelum menikah ada 17 anak. Pada Januari-Juni 2017, jumlah anak hamil sudah mencapai 73 anak.Dengan jumlah 12 anak yang sudah melakukan seks sebelum menikah.

Seks Pra-nikah atau pre-marital sex merupakan aktifitas seksual yang dilakukan tanpa adanya ikatan perkawinan yang sah. Pada umumnya aktivitas demikian dilakukan oleh pasangan muda-mudi yang sedang asyik tenggelam di dalam romantisme lautan asmara, dilakukan bisa jadi jenuh dengan pacar, atau bisa juga sekedar iseng ingin 
mencari pengalaman baru (Hasan, S \& Nasma, A, 2008).

Menurut Hasan, S \& Nasma, A (2010) Bentuk-bentuk seksual pranikah yang dilakukan itu biasanya beragam pula, mulai dari sekedar pegangan tangan, berciuman, berangkulan, petting (saling menggesekkan kelamin), sampai yang paling mengkhawatirkan, yakni melakukan hubungan kelamin (sex intercourse).

Berdasarkan hasil studi pendahuluan yang diperoleh dari Poli PKPR UPTD Puskesmas Sanan Wetan Kota Blitar, jumlah siswi tingkat pelajar SMA yang mengalami kejadian kehamilan tidak diinginkan pada 2017 rentang bulan Januari sampai bulan Juni tercatat terdapat 17 kasus. Di Poli PKPR UPTD Puskesmas Kepanjen kidul Kota Blitar tercatat 9 kasus dan 4 kasus terjadi di Poli PKPR UPTD Puskesmas Sukorejo. Dengan maraknya kasus seks pranikah pada remaja, tujuan penelitian ini ingin mengetahui mengenai bagaimanakah seks pranikah pada remaja.

\section{Metode}

Penelitian ini menggunakan desain penelitian deskriptif studi kasus (case study). Responden penelitian adalah dua remaja perempuan dengan umur 17-20 tahun (remaja akhir) yang pernah melakukan seks pranikah di Poli PKPR UPTD Puskesmas Sananwetan Kota Blitar. Pengumpulan data diambil melalui metode wawancara dan waktu pengambilan data dilakukan selama $3 x$ kunjungan rumah dalam 2 minggu.

\section{Hasil Dan Pembahasan}

Penelitian ini menggunakan dua responden remaja perempuan yang dikategorikan dalam masa perkembangan remaja akhir, kedua responden ini sebelumnya telah tercatat pernah mengunjungi Poli PKPR UPTD Puskesmas Sananwetan Kota Blitar, kedua responden memiliki umur yang sama yakni 17 tahun, terdapat perbedaan yang mencolok antara kedua responden, responden pertama dilahirkan dalam keluarga yang sederhana dan orangtua sudah cerai sejak duduk di bangku SD, kurangnya perhatian terhadap responden mengantarkan responden untuk melampiaskan rasa kekecewaannya dengan bergaul bersama teman sebayanya (anak jalanan) dan semenjak umur 14 tahun responden sudah melakukan seks pranikah dengan berganti-ganti pasangan tanpa menggunakan alat kontrasepsi dan menjadi penikmat tato dan alkohol.

Sedangkan responden yang kedua dilahirkan dalam keluarga yang mampu dan 
bersikap demokratis, sejak kecil responden dimanja dan dikekang, sehingga pada umur 16 tahun responden memberanikan diri untuk keluar rumah bersama teman lawan jenisnya, namun teman lawan jenis beserta keluarganya memberikan bujukan semacam ingin menikahi responden, selain dibujuk responden juga diberikan minuman teh yang membuat responden tidak sadarkan diri, sehingga teman lawan jenisnya leluasa dalam menguasai responden hingga melakukan hubungan intim layaknya suami istri.

Berdasarkan hasil penelitian dalam mengidentifikasi seks pranikah pada remaja menunjukkan bahwa satu remaja perempuan dari dua responden mengerti tentang seks pranikah hal ini sesuai dengan pernyataan yang disampaikan Hasan, S \& Nasma, A (2008) yang menyatakan bahwa seks pranikah merupakan aktifitas seksual yang dilakukan tanpa adanya ikatan perkawinan yang sah. Dan pada umumnya aktivitas demikian dilakukan oleh pasangan mudamudi yang sedang asyik tenggelam di dalam romantisme lautan asmara, dilakukan bisa jadi jenuh dengan pacar atau bisa juga sekedar iseng ingin mencari pengalaman baru.
Dari hasil penelitian didapatkan bahwa kedua responden melakukan seks pranikah dengan didahului proses berpacaran bersama teman lawan jenisnya, kemudian saling berpegangan tangan, berpelukan dengan penuh nafsu, berciuman dan berakhir pada berhubungan intim, dimana masa pacaran sebagai masa pendekatan antar individu dari kedua lawan jenis, yaitu ditandai dengan saling pengenalan pribadi baik kekurangan dan kelebihan dari masing-masing individu.

Paul dan White (1993) dalam jurnal psikologi Fridya Mayasari (2000) juga menyatakan bahwa pacaran melibatkan kemampuan untuk bergaul secara intim, akrab, terbuka, dan bersedia untuk melayani atau membantu individu yang lain jenis. Dalam masa pacaran, seorang individu dituntut untuk dapat memperhatikan kebutuhan orang yang dicintai. Sebab mencintai berarti memberi perhatian kepada orang lain, karena orang tersebut sudah sepantasnya ditolong, dibantu, dihargai, dijaga lebih dari sekedar orang lain atau teman. Dengan demikian, untuk mewujudkan cintanya terhadap seorang pacar, dengan kesadaran pribadi, seorang individu biasanya rela berkorban baik waktu, tenaga, maupun biaya untuk orang yang dicintainya. 
Dari proses berpacaran yng dilakukan oleh kedua responden peneliti beranggapan bahwa hubungan berpacaran bersama masing-masing teman lawan jenisnya merupakan hubungan berpacaran yang tidak sehat karena sudah melakukan hubungan intim layaknya suami istri tanpa didasari pernikahan yang sah.

Menurut teori yang dikemukakan oleh Herbert J. miles, (2000) dan Tim La Haye (1985) dalam Hasanudin (2017), terdapat standard berpacaran yang sehat yakni dimana ada beberapa standar berpacaran yang sehat yaitu diantaranya berpacaran adalah untuk anak-anak usia 15 tahun keatas.Walaupun lima belas tahun adalah umur yang direkomendasikan untuk mulai berpacaran, tidak berarti remaja harus dibatasi dalam menikmati hubungan mereka satu sama lain dalam kegiatan kelompok seperti: pesta, berkemah, olah raga, atau kegiatan keagamaan.

Standard selanjutnya yakni jangan pergi ke rumah pacar ketika tidak ada orang dewasa di rumah, atau waktu kunjung dibatasi tidak lebih dari seperempat jam. Di dalam mobil, remaja yang sedang kasmaran dapat melakukan hubungan seks. Demikian juga, rumah yang sepi merupakan lingkungan yang kondusif bagi remaja untuk melakukan hubungan seks. Tempat-tempat seperti ini harus jelas-jelas terlarang bagi remaja yang sedang berpacaran. Jika kedua remaja dari jenis kelamin yang berbeda berada di dalam satu rumah yang tidak dijaga, walaupun mereka tidak melakukan tindakan yang menyimpang, tidak adanya kehadiran orang lain atau orang tua dapat merusak reputasi mereka.

Hasil identifikasi kedua responden mengenai alasan dalam melakukan seks pranikah terdapat perbedaan yakni salah satu responden mengaku bahwa dalam melakukan hubungan seks pranikah bersama teman lawan jenisnya dilakukan atas dasar saling suka tanpa adanya paksaan, sedangkan pada responden kedua mengaku bahwa hubungan seks pranikah yang dilakukan atas dasar bujukan yang dilakukan pihak teman lawan jenisnya bersama keluarganya dengan alasan ingin menikahi responden, sehingga responden mengaku adanya bujukan dan pemberian minuman the yang membuat dirinya tak sadarkan diri dengan mudah dikuasai teman lawan jenisnya untuk melakukan hubungan seks pranikah.

Hasil identifikasi kedua responden tentang tahapan seksualitas yang dilakukan masing-masing responden memiliki 
kesamaan tahap yakni bersentuhan (touching), berciuman (kissing) dan berhubungan kelamin (seksual intercourse). Hal tersebut tidak sesuai dengan teori yang disampaikan oleh Sarwono (2015) yang menyatakan bahwa tahapan seksual yang dilakukan oleh remaja sebelum menikah dimulai dari bersentuhan (touching), berciuman (kissing), bercumbu (petting), dan berhubungan seksual (seksual intercourse).

Sehingga peneliti menyimpulkan bahwa tahapan yang dilakukan oleh kedua responden tidak sesuai teori yang disampaikan para ilmuwan karena hasil identifikasi menyatakan bahwa tahapan seksual yang dilakukan oleh kedua responden tanpa melalui tahap bercumbu (petting).

Hasil identifikasi mengenai dampak yang dirasakan masing-masing responden setelah melakukan seks pranikah yakni adanya rasa penyesalan yang teramat dalam karena dengan kejadian tersebut responden tidak dapat melanjutkan sekolah seperti teman sebayanya, dan dari kedua responden sudah jera dalam melakukan hubungan seks pranikah karena dampak yang ditimbulkan merusak cita-cita responden dan menimbulkan kehamilan, tetapi dari pengakuan kedua responden mengenai dampak yang dirasakan mengenai trauma psikologis tidak dirasakan. Hal ini tidak sesuai dengan pernyataan yang menjelaskan bahwa perilaku seksual yang dilakukan sebelum waktunya justru dapat memiliki dampak psikologis yang sangat serius, seperti rasa bersalah, depresi, marah, agresi (Simkins, 1984 dalam Sarwono 2015). Dampak psikologis lainnya adalah ketegangan mental dan kebingungan peran sosial yang tiba-tiba berubah, jika seorang gadis hamil diluar nikah, akan terjadi cemoohan dan penolakan dari masyarakat sekitarnya. (Sanderowitz \& Paxman, 1985 dalam Sarwono, 2015).

\section{Kesimpulan Dan Saran}

\section{Kesimpulan}

Berdasarkan hasil studi kasus diatas dapat disimpulkan bahwa seks pranikah yang dilakukan oleh dua responden remaja perempuan di Poli PKPR UPTD Puskesmas Sananwetan Kota Blitar diawali dari hubungan berpacaran bersama teman lawan jenisnya, dan hubungan seksual dilakukan pada saat kesempatan rumah kosong tanpa adanya pengawasan dari orang dewasa (orang tua). Responden pertama melakukan hubungan seksual pertama kali saat berumur 14 tahun dengan dasar perasaan saling suka 
dalam melakukan hal tersebut, sedangkan responden kedua melakukan hubungan seksual pertama kali pada umur 16 tahun dengan dilatarbelakangi adanya bujukan dan semacam jebakan yang dilakukan oleh pihak teman lawan jenis.

Aktifitas seksual pranikah yang dilakukan darikedua responden dalam penelitian tersebut tidak sesuai dengan 4 tahapan seksual yaitu bersentuhan (touching), berciuman (kissing), bercumbu (petting), dan berhubungan kelamin (seksual intercourse). Dari kedua responden dapat disimpulkan aktifitas seksual yang dilakukan tanpa melalui tahapan seksual bercumbu (Petting) tetapi dengan tahapan mengobrol bersama teman lawan jenisnya yang selanjutnya melakukan berpelukan dengan penuh nafsu (touching), berciuman (kissing) dan diakhiri dengan melakukan hubungan intim layaknya suami istri (seksual intercourse). Dalam penelitian ini juga menunjukkan bahwa remaja yang berpacaran tidak sehat cenderung berisiko untuk melakukan hubungan seksual sebelum menikah (seks pranikah).

\section{Saran}

\section{Bagi Tempat Penelitian}

Hasil penelitian ini dapat digunakan sebagai referensi untuk mengembangkan informasi tentang seks pranikah pada remaja sehingga dapat menjadi himbauan untuk lebih intensif dalam memberikan sosialisasi dan pendidikan kesehatan mengenai seks pranikah pada remaja dan diharapkan tempat penelitian khususnya Poli PKPR UPTD Puskesmas Sananwetan Kota Blitar dapat bekerja sama dengan orang tua beserta Dinas Pendidikan dan Dinas Sosial untuk lebih memperhatikan remaja dalam pergaulannya terutama dalam gaya berpacaran yang tidak sehat, sehingga dapat mengurangi dampak negatif yang terjadi akibat seks pranikah.

\section{Bagi Remaja}

Hasil penelitian ini dapat dijadikan remaja sebagai referensi untuk proses pembelajaran dan menambah wawasan tentang seks pranikah pada remaja.Sehingga diharapkan remaja mendapat pendampingan orang tua dan mempunyai kelompok konseling sebayasehinggadapat menghindari hubungan berpacaran bersama teman lawan jenisnya karena gaya berpacaran di era modern ini cenderung kearah negatif dan berujung pada hubungan seksual, menghindari tontonan film pornografi karena dapat meningkatkan gairah atau nafsu dalam melakukan hubungan seksual, dan meningkatkan keimanan kepada Tuhan 
Yang Maha Esa agar tidak terpengaruh dengan pergaulan bebas yang terjadi saat ini. Sehingga remaja dapat terhindarkan dari dampak negatif adanya seks pranikah seperti hamil diluar nikah dan penyakit menular seksual.

\section{Bagi Peneliti Selanjutnya}

Dari hasil penelitian ini diharapkan bagi peneliti selanjutnya dapat

\section{Referensi}

Hasanudin. (2017). Persepsi Antara Remaja Yang Berpacaran Dengan Remaja Yang Tidak Berpacaram Tentang Perilaku Seks Pranikah. Blitar: Poltekkes Malang.

Hasan S, \& Nasma A. (2010). Let's Talk About Love. Solo: TIGA SERANGKAI.

Mayasari, Fridya. (2000). Jurnal Kesehatan Pendidikan Seks.(2010). Metodologi Penelitian Kesehatan. Jakarta: Rineka Cipta mengembangkan penelitian ini pada isu-isu yang terjadi terhadap remaja saat ini, terutama remaja yang melakukan hubungan berpacaran tidak sehat, peneliti selanjutnya dapat meneliti tentang hubungan antara pacaran dengan aktifitas seks pranikah, hal tersebut dapat membuktikan bahwa berpacaran merupakan salah satu faktor dalam melakukan aktifitas seks pranikah.

Nursalam. (2013). Metodologi Penelitian Ilmu Keperawan Pendekatan Praktis Edisi 3. Jakarta: Salemba Medika.

Sarwono, Sarlito W. (2011). Psikologi Remaja. Jakarta: PT Raja Grafindo Persada.

Sarwono, Sarlito W. (2015). Psikologi Remaja. Jakarta: PT Raja

Soetjiningsih. (1995). Tumbuh Kembang Anak. Jakarta:EGC. 